\title{
ANALYSIS OF CONTENTS OF ANNUAL SUSTAINABILITY REPORTS OF INDUSTRIAL COMPANIES PARTICIPATING IN THE SUSTAINABILITY INDEX OF THE BRAZILIAN STOCK EXCHANGE
}

\author{
ANÁLISE DE CONTEÚDO DOS RELATÓRIOS \\ ANUAIS DE SUSTENTABILIDADE DAS \\ EMPRESAS INDUSTRIAIS PARTICIPANTES \\ DO ÍNDICE DE SUSTENTABILIDADE DA BOLSA \\ DE VALORES BRASILEIRA
}

Submission: 04/05/2019 Accept: 15/11/2019

Ademir Clemente ${ }^{1}$ Flávio Ribeiro ${ }^{2}$ Otávio Augusto de Paula da Silva ${ }^{3}$ Núbbia Mendonça Oliveira ${ }^{4}$

\begin{abstract}
The objective of this article is to analyze the content of environmental disclosure of industrial companies participating in the Corporate Sustainability Index (ISE) of the Brazilian Stock Exchange (B3) from 2009 to 2016, based on the Stakeholders' Theory perspective. We adopt a descriptive approach, with qualitative and quantitative analysis of secondary data that we analyze by means of content analysis and statistical techniques. The data collection took place from the institutional site of each organization to obtain the Annual Sustainability Reports. The reports went through text analysis, which resulted in an inventory of words related to the concept of sustainability. The results indicate that the analyzed companies have similarities with regard to the content disclosed in the Annual Sustainability Reports. Such similarities occur in spite of the fact that companies operate in different industrial segments (petrochemical, food, wood, pulp and paper products and personal use products) and probably come from a homogeneous perception of the segments interested in the information, which would be in reduced number. Although the surveyed companies operate in different segments, they are subject to similar pressures by stakeholders and that imposes an apparent homogeneity to their reports.
\end{abstract}

Keywords:Sustainability. Sustainable development. ISE. Environment. Content analysis.

\footnotetext{
1 PhD in Transport Engineering from the Federal University of Rio de Janeiro. Federal University of Paraná, Curitiba, Paraná, Brazil. E-mail: ademir@ufpr.br ORCID: http://orcid.org/0000-0002-3998-6263

2 PhD in Accounting Science from the Federal University of Paraná. Federal University of Paraná, Brazil. E-mail: flavioribeiro@unicentro.br ORCID: http://orcid.org/0000-0002-3547-9539

3 Master in Accounting from the Federal University of Paraná. Federal University of Paraná, Curitiba, Paraná, Brazil. E-mail: otavioaugustops1@gmail.com ORCID: http://orcid.org/0000-0002-6153-7165

4 Master in Accounting from the Federal University of Paraná. Federal University of Paraná, Curitiba, Paraná, Brazil. E-mail: nubbia.oliveira@ufpr.br ORCID: http://orcid.org/0000-0002-1653-0781
} 


\section{RESUMO}

O objetivo deste estudo é analisar o conteúdo da divulgação ambiental das empresas industriais participantes do Índice de Sustentabilidade Empresarial (ISE) da Bolsa de Valores Brasileira (B3) no período de 2009 a 2016, tomando como base a perspectiva da teoria dos stakeholders. Trata-se de uma pesquisa descritiva, com análise quali-quantitativa de dados secundários, efetuando análise por meio de análise de conteúdo e técnicas estatísticas. A coleta de dados ocorreu a partir do site institucional de cada organização para a obtenção dos Relatórios Anuais de Sustentabilidade. Os relatórios passaram por análise de texto da qual resultou um inventário das palavras relacionadas ao conceito de sustentabilidade. Os resultados indicam que as empresas analisadas possuem semelhanças no que diz respeito ao conteúdo divulgado nos Relatórios Anuais de Sustentabilidade. Tais semelhanças ocorrem a despeito de as empresas atuarem em segmentos industriais distintos (petroquímica, alimentícia, madeireira, papel e celulose e produtos de uso pessoal) e advêm, provavelmente, de uma percepção homogênea quanto aos segmentos interessados na informação, os quais seriam em número reduzido. Embora as empresas pesquisadas operem em diferentes segmentos, estão sujeitas a pressões similares advindas dos stakeholders e isso impõe uma perceptível homogeneidade aos seus relatórios.

Palavras-chave: Sustentabilidade. Desenvolvimento Sustentável. ISE. Meio Ambiente. Análise de Conteúdo.

\section{INTRODUCTION}

The perspective of the shareholders (FRIEDMAN , 1970) and the stakeholder perspective (LEVITT , 1958; CARROLL , 1979; FREEMAN , 1984) are the two main theories underlying the study of the role of organizations in society. The shareholder perspective chooses to maximize shareholder value; on the other hand, the stakeholder perspective points to the organization as conscious agents that contribute to the sustainable development of the community of which it is a part, including the preservation of natural resources for future generations.

Corporate Social Responsibility (CSR) currently represents for organizations a strategic and preponderant instrument for legitimizing the management practices and policies used by companies vis-à-vis society. The CSR has its bases mainly on the theory of the shareholders and the theory of the stakeholders. The first theory reflects the evolution of capitalism, and advocates the maximization of shareholder value (FRIEDMAN , 1970; FRIEDMAN ; FRIEDMAN, 1977). The second one, the Stakeholders' Theory advocated by Levitt (1958), Carroll (1979) and Freeman (1984), demonstrates the social responsibility of organizations to the demand of a larger public not restricted to their shareholders. Such a larger public includes their clients, suppliers, government, employees and creditors and any group potentially interested in the existence and functioning of the company.

For Gray, Bebbington and Walters (1993) the investments made by companies in the socio-environmental context is no longer a differential, but an obligation from the point of view of the socio-economic agent. Due to the integration of global markets and the increase of competitiveness among companies, society tends to privilege organizations that present management strategies aimed at protecting their interests, especially environmental preservation.

According to Griffin and Mahon (1997), since the 1970s, Stakeholders' Theory has been the focus of numerous empirical studies aimed at verifying whether there is a relationship between corporate CSR practices and policies with financial performance. In this respect, the published research, both national and international, presents diverse and even contradictory results, giving rise to intense debate. Brito (2005), after compiling the research on the association between environmental and financial performance, found that the results are not conclusive, finding positive, null and even negative correlations, depending on the context, sample and method- 
ology used. Some authors affirm that the economic-financial motivations for the incorporation of the sustainability in the activities of the organizations depend on the context of the firm, of the sector, and especially of the country (STEGER, 2004; REED, 2001).

According to Epstein (2003), the integration of social and environmental aspects in companies occurs when managers find a business justification for good social and environmental performance. However, according to López, Garcia and Rodriguez (2007), the success of organizations is broader, involving the integration of concepts such as managerial quality, environmental management, brand reputation, consumer loyalty, corporate ethics and retention of talent. Nevertheless, some companies just follow the "Kantian" thought because they believe it is "the right thing to do" and simply act responsibly. For Wajnberg (2008), for example, the "Kantian" justification is vulnerable to the organizational changes, financial cycles and priorities of the companies, making the implantation of lasting socio-environmental projects in the organizations unlikely.

Based on these considerations, the following research question is admitted: What is the content of the environmental disclosure of industrial companies belonging to the Corporate Sustainability Index (ISE)? Thus, the objective of this article is to analyze the content of environmental disclosure of industrial companies participating in ISE in the period from 2009 to 2016, based on the perspective of Stakeholders' Theory. In order to achieve the purpose of this article, we carried out a search for keywords associated with the concept of sustainability in the Annual Sustainability Report of the selected companies.

The article contributes to filling gaps related to the understanding of environmental aspects that reflect in the organizational disclosure process. Specifically, when considering the industrial segment companies participating in the ISE. It should be noted that the related studies aimed to highlight the level of voluntary environmental disclosure in services and industries (CALIXTO, 2007) and for highly polluting segments (ROVER, et al., 2008; DE OLIVEIRA, MACHADO AND BEUREN, 2012). However we did not find studies that dealt strictly with the same search strategy, which represents a useful possibility to insert it in the theoretical discussion and, consequently, in the empirical verification among the actors in the field of corporate finance.

The remaining of this article is as follows: presentation of the theoretical-empirical reference used, methodological notes, analysis of results, and conclusions.

\section{THEORETICAL-EMPIRICAL FOUNDATION}

This section includes the following topics: Stakeholders' Theory, Sustainability, Corporate Social Responsibility and Corporate Sustainability Index.

\subsection{Stakeholders' Theory}

The Stakeholders' Theory consists of a set of ethical or normative approaches that stand out for different reasons, admitting the importance of stakeholders in the development of any business entity. According to Gray, Owen and Adams (1996), it is a theory whose purpose is determined by the systemic approach of all the elements that constitute an organization, including its internal and external environment, and recognizing the dynamic and complex nature of influence between them.

Nevertheless, for Cintra and Martins (2009) the Stakeholders' Theory allows the business entities understanding that the incentive to the fulfillment the expectations of the stakeholders is justified by the fact that the company behaves like a conscious agent oriented by the 
moral and ethical principles. In a certain way, this is compatible with the Kantian vision, that the fulfillment of the expectations of the stakeholders is the right thing to do. Campbell (2007) argues that such a theory examines when and why organizations serve the interests of their stakeholders, regardless of organizational interests.

The word stakeholder was first used in 1963 in an internal memo of the Stanford Research Institute, initially referring to all groups without which a company would cease to exist (SILVEIRA; BORBA; YOSHINAGA, 2005). For Freeman (1984), managers need to understand the real needs of stakeholders to achieve organizational goals. Any individual who influences or is influenced directly or indirectly by the achievement of the company's goals is considered a stakeholder. On the other hand, Jensen (2001), contrary to Freeman's(1984) definition, admits a certain confusion in its interpretation, since it would consider the environment, terrorists and criminals as stakeholders, as they could substantially affect or be affected by the a company's activities.

Donaldson and Preston (1995) understand that there is a multiplicity of stakeholder definitions, which varies according to the scope. In the broadest sense, stakeholder is any actor (person, group, entity) that has a relationship or interest (direct or indirect) in the organization. In the strictest sense, primary stakeholder is an actor (or category of actors, such as employees, managers, suppliers, owners or shareholders, and clients), bearer of interests and expectations regarding the organization, without which the organization could not exist (SILVEIRA; YOSHINAGA; BORBA, 2005).

According to Silveira, Yoshinaga and Borba (2005), Stakeholders' Theory emerged in sociology, based on the study and analysis of organizational behavior and the politics of interests of specific groups. Thus, this theory leads to the formulation and implementation, by the administrators, of processes that take into account all the interests at stake of all the groups involved. According to this view, managers' main task is to manage and integrate the relationships and interests of shareholders, employees, customers, suppliers, communities and other groups, ensuring the company's success over time (FREEMAN; MCVEA, 2000).

For López, Garcia and Rodriguez (2007), Stakeholders' Theory ends up being a counterpoint to classical economic theory, since it seeks the development of corporate practices that, in addition to including goals that aim to maximize shareholder interests, incorporate the perspective of stakeholders' satisfaction. After all, stakeholder satisfaction represents the survival and success of organizations.

CSR, as well as Stakeholders' Theory, highlights the special concern and attention expected of business entities in relation to social and environmental issues, which could result in superior economic performance and long-term value creation (GARRIGA; MELÉ, 2004). Although there is no disagreement in this regard, CSR's implementation in practice faces the great difficulty of reconciling the view of shareholders with the perspective of other stakeholders. Shareholders present specific interests that often conflict with the other stakeholders' interests (CINTRA; MARTINS, 2009).

\subsection{Sustainability}

The main reference of the concept of sustainability is the idea of a global framework for meeting current and future human needs (BRUNDTLAND, 1987 apud DUMAY \& HOSSAIN, 2019).

We analyze sustainability according to three interrelated dimensions: social, economic and environmental. (ELKINGTON, 1997). Sustainability analysis according to its pillars provides an integrative concept for the formulation of strategies and, from the isolated observation of these pillars, there may be deeper contributions and less political resistance. (GIBSON, 2008). 
Thus, by observing sustainability according to its three dimensions, we can draw up plans so that society and the environment do not perish and continue to provide their essential services for future generations. In other words, in order to achieve true sustainability, it is essential to adopt a holistic vision and not just emphasize business efficiency (GRINDE \& KHARE, 2008). This requires corporations to address environmental issues with integrity and accountability to ensure real sustainability conditions (BANERJEE, 2008). As Moldan, Janoušková \& Hák (2012) argue, there has been a positive evolution towards sustainability. This was a vague concept in recent decades, but now it has conditions for quantitative operationalization.

Although there are positions with a greater or lesser degree of criticism regarding sustainability and its markings, the notion of sustainability is dynamic and changeable, requiring synergistic advances between governance and cooperation in the face of new ecological challenges (VEIGA, 2014). However, it is true that the deepening of the concept, as well as the improvement and consolidation of its operationalization, are at the center of the concerns of the future of the human species (PURVIS, MAO \& ROBINSON, 2019).

\subsection{Corporate Social Responsibility}

The term Corporate Social Responsibility (CSR) began to be used as early as the 1930s, but gained prominence in 1953, the year of publication of the book entitled Social Responsibilities of the Businessman, authored by Howard R. Bowen (CARROLL, 1979). CSR studies oscillate between two extremes: the first reduces responsibility for achieving maximum benefit to shareholders (Friedman, 1970), while the latter extends responsibility to a range of agents with whom the company relates in society, i.e. employees, suppliers, customers, unions, competitors, creditors, government entities and other interest groups (ARGANDOÑA, 1998).

The broader concept of CSR is the one adopted in most studies, CSR being understood as the set of voluntary practices that companies carry out with the objective of promoting improvements in the social and environmental conditions. CSR requires that corporations actuate to improve the environment in which they operate, responding not only to capital appreciation as well as technical and legal requirements, in order to benefit the population with the improvement of social and environmental conditions (CARROL, 1979; CAMPBELL, 2007).

The process of changing management and evolution of the social function of business, according to Gray (2002), was considered in the 1990s as the milestone of a "New Organization", in which dialogue and dynamic exchange with stakeholders are recurrent. According to Tinoco and Kraemer (2004), this process is predefined, resulting in changes mainly in the organizational structure, planning activities, responsibilities, practices, procedures, processes and resources to develop, implement, achieve, critically analyze and maintain environmental policy. This is what the company should do to minimize or eliminate the negative effects of its activities on the environment.

\subsection{Corporate Sustainability Index}

The International Finance Corporation (IFC), the World Bank's financial arm, originally funded the Business Sustainability Index (ISE), started in 2005. The School of Business Administration of São Paulo, Fundação Getúlio Vargas (FGV-EAESP), developed its methodological design. ISE aims to provide an investment environment compatible with the demands of sustainable development of society and to stimulate the ethical responsibility of organizations (B3, 2018). 
The initial proposal was to release the progress of ISE over time and to highlight the main events that occurred in each period. However, that proposal was adjusted to keep in constant evolution, providing the condition to insert new facts in the methodology. Considered as a comparative benchmarking tool for companies listed on B3, ISE reflects corporate sustainability based on environmental balance, economic efficiency, social justice and corporate governance (FGV-EAESP, 2015).

The ISE provides a comprehensive view of the organizations and groups involved in sustainability, distinguishing them in terms of quality, commitment to sustainable development, transparency and accountability, and product nature, as well as providing differentiation in business performance in the economic, financial and social dimensions (B3, 2018).

\section{METHODOLOGICAL NOTES}

This section contains the characterization of the research carried out and information about the procedures adopted.

\subsection{Research Characterization}

The research is descriptive in nature, with qualitative and quantitative analysis of secondary data and the use of statistical instruments, seeking to describe the content of environmental disclosure of industrial companies belonging to ISE. According to Gil (2002), the research also has historical-bibliographic, documentary and empirical characteristics, since it is based on the information contained in the annual sustainability reports.

\subsection{Population, sample and data collection}

The population of the present research comprises the companies listed in the Corporate Sustainability Index (ISE). The research sample was restricted to industrial organizations belonging to the ISE from 2009 to 2016.

The companies were chosen through a survey on the B3 website, selecting 49 (forty-nine) companies inserted in the ISE during the period from 2009 to 2016. Of these, we withdrew financial institutions, department stores and telephone companies, reducing the number of companies to 33 (thirty-three). Then, applying as a selection criterion the participation in the ISE in the whole eight-year period, since its inception, remained only 11 (eleven) companies. Of these, we still excluded electric power companies because they are subject to specific legislation and regulations.

At the end of this process, the final sample resulted in only five companies. These companies presented the Annual Sustainability Report for all the years of the period and operate in the segments of (1) petrochemicals - BRASKEM, (2) food - BRF, (3) timber - DURATEX, (4) pulp and paper - FIBRIA, and (5) products for personal use - NATURA.

We obtained the Annual Sustainability Reports for content analysis from the institutional website of each organization. The reports went through text analysis, for the systematization of the content, which resulted in an inventory of the words related to the concept of sustainability. The content analysis followed, in general terms, the methodology originally proposed by Bardin (1977).

The text analysis initially sought to quantify in the reports the occurrence of words and technical terms related to the environment and sustainability such as energy, water, materials, 
forest, biodiversity, environmental impact, waste, utilization, compliance, degradation, among others (GRI, 2017).

\section{ANALYSIS OF RESULTS}

Table 1 contains a demonstration of the evocation of concepts strictly related to environmental disclosure in the Annual Sustainability Reports of selected companies, from 2009 to 2016.

Table 1: Evocation of concepts related to environmental disclosure, from 2009 to 2016

\begin{tabular}{|c|c|c|c|c|c|c|c|c|c|c|}
\hline CONCEPT & COMPANY & 2009 & 2010 & 2011 & 2012 & 2013 & 2014 & 2015 & 2016 & TOTAL \\
\hline \multirow{6}{*}{$\begin{array}{l}\text { Sustainable } \\
\text { development }\end{array}$} & Braskem & 8 & 65 & 71 & 29 & 44 & 71 & 48 & 34 & 370 \\
\hline & BRF & 0 & 2 & 4 & 11 & 6 & 4 & 18 & 0 & 45 \\
\hline & Duratex & 1 & 5 & 5 & 1 & 0 & 4 & 4 & 22 & 42 \\
\hline & Fibria & 6 & 15 & 17 & 2 & 6 & 2 & 3 & 1 & 52 \\
\hline & Natura & 22 & 14 & 0 & 26 & 9 & 8 & 4 & 5 & 88 \\
\hline & Subtotal & 37 & 101 & 97 & 69 & 65 & 89 & 77 & 62 & 597 \\
\hline \multirow{6}{*}{$\begin{array}{l}\text { Environmen- } \\
\text { tal impact }\end{array}$} & Braskem & 0 & 0 & 7 & 5 & 3 & 11 & 3 & 5 & 34 \\
\hline & BRF & 4 & 2 & 4 & 2 & 4 & 3 & 6 & 0 & 25 \\
\hline & Duratex & 0 & 1 & 3 & 1 & 2 & 4 & 4 & 5 & 20 \\
\hline & Fibria & 6 & 6 & 13 & 3 & 1 & 4 & 1 & 0 & 34 \\
\hline & Natura & 5 & 11 & 7 & 12 & 4 & 2 & 1 & 2 & 44 \\
\hline & Subtotal & 15 & 20 & 34 & 23 & 14 & 24 & 15 & 12 & 157 \\
\hline \multirow{6}{*}{ Environment } & Braskem & 12 & 0 & 60 & 61 & 32 & 77 & 33 & 34 & 309 \\
\hline & BRF & 10 & 27 & 32 & 25 & 32 & 18 & 28 & 0 & 172 \\
\hline & Duratex & 21 & 19 & 21 & 22 & 11 & 14 & 1 & 8 & 117 \\
\hline & Fibria & 36 & 76 & 55 & 8 & 13 & 16 & 14 & 7 & 225 \\
\hline & Natura & 20 & 11 & 14 & 19 & 4 & 5 & 2 & 1 & 76 \\
\hline & Subtotal & 99 & 133 & 182 & 135 & 92 & 130 & 78 & 50 & 899 \\
\hline \multicolumn{2}{|c|}{ TOTAL } & 151 & 254 & 313 & 227 & 171 & 243 & 170 & 124 & 1,653 \\
\hline
\end{tabular}

Source: Authors (2019).

The concept of Sustainable Development appears with great emphasis in Braskem's Annual Sustainability Reports, a company that operates in the petrochemical sector. Regarding the concept of Environmental Impact, we observe a relatively low frequency in the Annual Sustainability Reports of all the sampled companies, without great disparities between them. The concept of Environment is the one that presents greater occurrence. The dimension related to environmental impact can be grouped into the one referring to the environment and, then, the result is double of occurrences with respect to sustainable development dimension.

The words related to sustainability, manually selected in the reports of the 5 companies sampled in the period from 2009 to 2016, presented the occurrences shown in Table 2. 
Table 2: Occurrences of words related to sustainability

\begin{tabular}{|c|c|c|c|c|c|c|c|}
\hline $\mathrm{N}$ & WORD & BRASKEM & BRF & DURATEX & FIBRIA & NATURA & TOTAL \\
\hline 1 & ENVIRONMENTAL & 867 & 472 & 673 & 816 & 351 & 3,179 \\
\hline 2 & ENVIRONMENT & 443 & 268 & 204 & 316 & 175 & 1,406 \\
\hline 3 & ACCEPTANCE & 35 & 12 & 35 & 46 & 44 & 172 \\
\hline 4 & LEASING & 10 & 35 & 114 & 99 & 148 & 406 \\
\hline 5 & BIODIVERSITY & 70 & 74 & 94 & 272 & 205 & 715 \\
\hline 6 & BIOLOGICAL & 45 & 77 & 222 & 211 & 12 & 567 \\
\hline 7 & BIOMASS & 18 & 27 & 65 & 96 & 11 & 217 \\
\hline 8 & AWARENESS & 59 & 38 & 27 & 45 & 22 & 191 \\
\hline 9 & CONSERVATION & 35 & 55 & 118 & 293 & 70 & 571 \\
\hline 10 & CRISIS & 35 & 19 & 19 & 45 & 17 & 135 \\
\hline 11 & SPILLS & 39 & 19 & 11 & 12 & 8 & 89 \\
\hline 12 & CHALLENGES & 157 & 94 & 56 & 119 & 63 & 489 \\
\hline 13 & DEVELOPMENT & 1397 & 634 & 572 & 955 & 593 & 4,151 \\
\hline 14 & DAMAGE & 161 & 83 & 140 & 456 & 58 & 898 \\
\hline 15 & ECOLOGICAL & 32 & 1 & 3 & 81 & 21 & 138 \\
\hline 16 & ETHICS & 165 & 157 & 226 & 92 & 79 & 719 \\
\hline 17 & EVOLUTION & 265 & 67 & 72 & 73 & 232 & 709 \\
\hline 18 & FORESTS & 73 & 35 & 773 & 2198 & 54 & 3,133 \\
\hline 19 & GOVERNANCE & 265 & 234 & 344 & 280 & 137 & 1,260 \\
\hline 20 & IMPACT & 518 & 512 & 429 & 618 & 400 & 2,477 \\
\hline 21 & INNOVATIONS & 328 & 278 & 164 & 231 & 478 & 1,479 \\
\hline 22 & NATURAL & 83 & 84 & 146 & 224 & 53 & 590 \\
\hline 23 & NATURE & 58 & 52 & 95 & 54 & 84 & 343 \\
\hline 24 & NEGATIVES & 50 & 98 & 40 & 102 & 38 & 328 \\
\hline 25 & DANGEROUS & 79 & 45 & 42 & 52 & 26 & 244 \\
\hline 26 & PLANTATION & 30 & 8 & 58 & 410 & 9 & 515 \\
\hline 27 & PRESERVATION & 85 & 78 & 99 & 121 & 28 & 411 \\
\hline 28 & RECYCLING & 378 & 162 & 100 & 137 & 154 & 931 \\
\hline 29 & RECOVERY & 281 & 102 & 303 & 182 & 106 & 974 \\
\hline 30 & RESOURCES & 186 & 201 & 231 & 383 & 400 & 1,401 \\
\hline 31 & REDUCTIONS & 573 & 586 & 430 & 499 & 304 & 2,392 \\
\hline 32 & RENEWABLE & 370 & 135 & 105 & 136 & 55 & 801 \\
\hline 33 & RESIDUES & 438 & 236 & 234 & 376 & 278 & 1,562 \\
\hline 34 & RESPONSIBILITY & 409 & 255 & 337 & 325 & 116 & 1,442 \\
\hline 35 & RESTORATION & 8 & 8 & 14 & 189 & 6 & 225 \\
\hline 36 & REUSABLE & 56 & 32 & 102 & 56 & 21 & 267 \\
\hline 37 & RISKS & 391 & 561 & 801 & 630 & 627 & 3,010 \\
\hline 38 & SAFETY & 706 & 338 & 274 & 308 & 180 & 1,806 \\
\hline 39 & SOCIAL & 657 & 516 & 770 & 591 & 707 & 3,241 \\
\hline 40 & SOCIETY & 155 & 129 & 130 & $14 \overline{3}$ & 1484 & 2,041 \\
\hline 41 & SOCIO-ENVIRONMENTAL & 288 & 81 & 145 & 229 & 162 & 905 \\
\hline 42 & SUSTAINABILITY & 566 & 469 & 1380 & 1282 & 401 & 4,098 \\
\hline 43 & SUSTAINABLE & 573 & 194 & 126 & 238 & 365 & 1,496 \\
\hline 44 & TECHNOLOGIES & 220 & 83 & 98 & 170 & 326 & 897 \\
\hline 45 & VALORIZATION & 294 & 89 & 41 & 80 & 70 & 574 \\
\hline 46 & GREEN & 288 & 113 & 23 & 69 & 36 & 529 \\
\hline & TOTAL & 12,239 & 7,846 & 10,485 & 14,340 & 9,214 & 54,124 \\
\hline
\end{tabular}

Source: Authors (2019).

Charles Edward Spearman's Rank Correlation Analysis involving the frequencies of all the words related to sustainability throughout the period from 2009 to 2016 provided the results shown in Table 3.

Table 3: Spearman correlation coefficients between the frequencies of words related to sustainability

\begin{tabular}{|c|c|c|c|c|}
\hline & BRASKEM & BRF & DURATEX & FIBRIA \\
\hline BRF & $\begin{array}{c}0.912 \\
(14.75)\end{array}$ & & & \\
\hline DURATEX & $\begin{array}{l}0.677 \\
(6.10)\end{array}$ & $\begin{array}{l}0.760 \\
(7.76)\end{array}$ & & \\
\hline FIBRIA & $\begin{array}{l}0.568 \\
(4.58)\end{array}$ & $\begin{array}{l}0.637 \\
(5.48)\end{array}$ & $\begin{array}{l}\mathbf{0 . 8 2 2} \\
(9.57)\end{array}$ & \\
\hline NATURA & $\begin{array}{l}0.753 \\
(7.59)\end{array}$ & $\begin{array}{l}0.796 \\
(8.72)\end{array}$ & $\begin{array}{l}0.685 \\
(6.24)\end{array}$ & $\begin{array}{l}0.590 \\
(4.85)\end{array}$ \\
\hline
\end{tabular}

Note: Student's t in parentheses.

Source: Authors (2019). 
Based on the values of Student's t statistic, we verify that all the estimated correlation coefficients have a level of significance lower than $0.1 \%$. It is worth noting the estimated correlation between BRF and BRASKEM, equal to 0.912, the first being in the food sector and the second in the petrochemical sector. Two further correlations are very high. The first correlation is between FIBRIA, a company of the pulp and paper sector, and DURATEX, of the wood segment, which reaches 0.822 . The second correlation is between NATURA, personal use products, and BRF, which reaches 0.796 .

The statistical analysis in Table 3 shows evidence that the contents of the Annual Sustainability Reports of the analyzed companies are, in general, highly correlated. That is to say, even though companies operate in distinct sectors, they evoke the words related to sustainability in a similar way, indicating a great coincidence in their emphases. The analysis of commercial companies and polluting industries found differences and gaps between the disclosed information and the presented format (CALIXTO, 2007). Regarding highly polluting companies, the study by the authors De Oliveira, Machado and Beuren (2012) found profound differences between sectors and companies, as well as omissions of information, at least in the period 2008 and 2009 of companies belonging to the ISE.

In relation to the three dimensions of sustainability, the Qui-square test for the differences between the companies is presented in Table 4 .

Table 4: Qui-square test for differences in relation to the three dimensions of sustainability

\begin{tabular}{c|c|c|c}
\hline Company & $\begin{array}{c}\text { Sustainable } \\
\text { development }\end{array}$ & Environmental impact & Environment \\
\hline Braskem & 370 & 34 & 309 \\
\hline BRF & 45 & 25 & 172 \\
\hline Duratex & 42 & 20 & 117 \\
\hline Fibria & 52 & 34 & 225 \\
\hline Natura & 88 & 44 & 76 \\
\hline TOTAL & 597 & 157 & 899 \\
\hline Qui-square & 668.8 & 10.83 & 186.4 \\
\hline Critical value at 1\% & 13.28 & 13.28 & 13.28 \\
\hline
\end{tabular}

Source: Authors (2019).

Table 4 shows that companies are well differentiated in relation to sustainability dimensions, with the exception of environmental impact, for which the value of chi-square does not show significant. In fact, the frequencies of the words used in the reports for reference to environmental impact are very similar, in addition of being actually much less numerous.

Taking into account the framework of Stakeholders' Theory, the previous statistical evidence indicates that the perception of the sampled companies regarding the external environment is very homogeneous and, probably, they perceive very narrowly the set of stakeholders. Therefore, Corporate Social Responsibility, and particularly Corporate Environmental Responsibility, that one infers from the contents published in the Annual Sustainability Reports, are very similar, although the analyzed industrial companies operate in different segments (petrochemical, food, timber, pulp and paper and products for personal use).

Table 5 shows the evolution of the set of reports of the five companies year by year in terms of the simple correlation coefficient. 
Table 5: Correlation coefficients between occurrences of words year by year

\begin{tabular}{cccccccc}
\hline YEAR & $\mathbf{2 0 0 9}$ & $\mathbf{2 0 1 0}$ & $\mathbf{2 0 1 1}$ & $\mathbf{2 0 1 2}$ & $\mathbf{2 0 1 3}$ & $\mathbf{2 0 1 4}$ & $\mathbf{2 0 1 5}$ \\
\hline $\mathbf{2 0 1 0}$ & 0.617 & 1 & & & & & \\
$\mathbf{2 0 1 1}$ & 0.415 & 0.718 & 1 & & & & \\
$\mathbf{2 0 1 2}$ & 0.310 & 0.101 & 0.616 & 1 & & & \\
$\mathbf{2 0 1 3}$ & 0.198 & 0.539 & 0.855 & 0.740 & 1 & & 1 \\
$\mathbf{2 0 1 4}$ & 0.124 & 0.352 & 0.858 & 0.813 & 0.870 & & 1 \\
$\mathbf{2 0 1 5}$ & 0.028 & 0.493 & 0.817 & 0.637 & 0.937 & 0.858 & 0.675 \\
\hline $\mathbf{2 0 1 6}$ & 0.011 & 0.267 & 0.687 & 0.614 & 0.643 & 0.868 & \\
\hline
\end{tabular}

Source: Authors (2019).

The association between the profiles of sustainability terms used in a year and the next, indicated by the correlation coefficients located just below the main diagonal, is generally moderate. However, it reaches relatively high values in the period from 2013 to 2015. It is also possible to notice a profound change in the pattern of association between the profiles in 2011, since the correlations that the profiles of 2009 and 2010 present with the others are the lowest. Possibly, that such a change is associated with the mandatory adoption of international accounting standards in 2010. For Acerete, Gasca and Llena (2019), environmental information tends to comply only with normative requirements and without presenting richer content, however, it should be noted that in the spanish scenario, there was a loss of quality in information as well as a reduction in evidenced content. after IFRS.

In order to reduce the amount of data involved and facilitate further interpretation, we performed Principal Component Analysis on the representative positions of the importance of the variables in the Annual Sustainability Reports. The results indicate that the first component accounts for $64.39 \%$, almost two thirds, of the total variation. Examining the correlations of the variables with the first principal component, shown in Table 6, we have an indication that the published content related to sustainability does not present significant differences between the Annual Sustainability Reports of the analyzed industrial companies.

Table 6: Correlations with the first Principal Component

\begin{tabular}{c|c}
\hline Companies & Principal Component 1 \\
\hline BRASKEM & 0.833 \\
\hline BRF & 0.915 \\
\hline DURATEX & 0.885 \\
\hline FIBRIA & 0.721 \\
\hline NATURA & 0.622
\end{tabular}

Source: Authors (2019).

The results shown in Table 6 indicate once again that the Annual Sustainability Reports of the companies analyzed are, in essence, very similar to each other. If, on the one hand, a certain level of similarity could arise because the reports are of the same type, on the other hand, as companies operating in distinct sectors, with different effects on the environment, it is surprising to note a common core of conceptual emphases. In other words, the similarity between the contents disclosed by the surveyed industrial companies indicates similar views regarding the external environment. Thus, recalling the Stakeholders' Theory, we suggest that the companies address such a content to a small variety of interested segments, which would be virtually the same, perhaps with the exception of the content evidenced by Natura, the company of the segment of cosmetics. 
Banerjee (2008) analyzed CSR and found that corporations construct and modulate their speech for the stakeholders. In line with this, Furtado et al (2019) did not find how the reported sustainability practices, as well as innovations, changed or changed the habits of society. Moreover, in both research papers the authors ask whether there is a genuine search for CSR or just the legitimation of their images.

Continuing with the Principal Component Analysis, we subdivide the words related to sustainability according to the sign of the estimated load on the first principal component representing the variation observed in the companies as a whole. Figure 1 shows the performance of the words that present positive loads on the mentioned component.

Figure 1: Words with Positive Loads

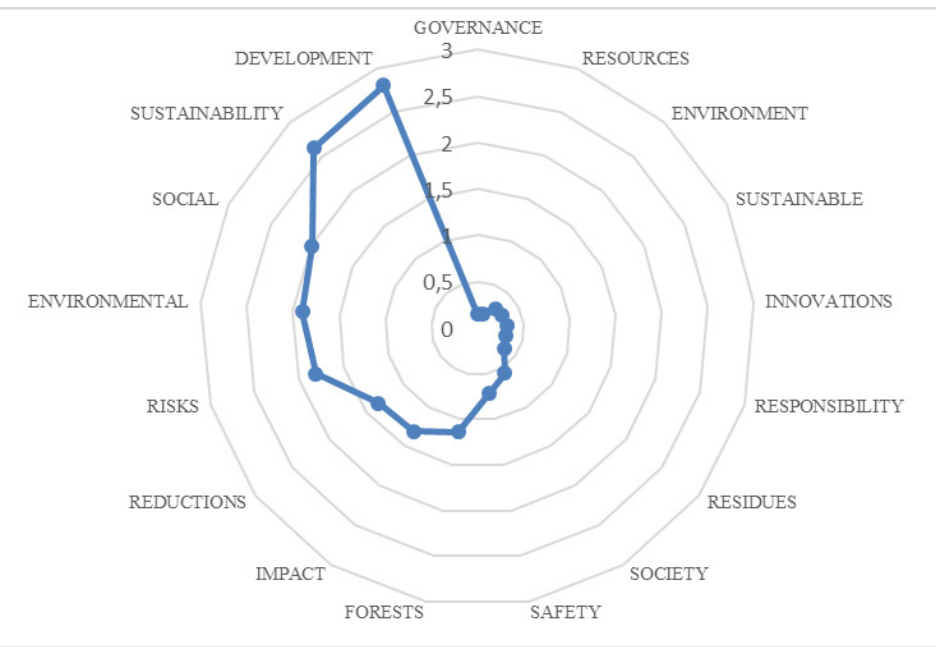

Source: Authors (2019).

Figure 2 shows the performance of the words that present negative loads on the first principal component.

Figure 2: Words with Negative Loads

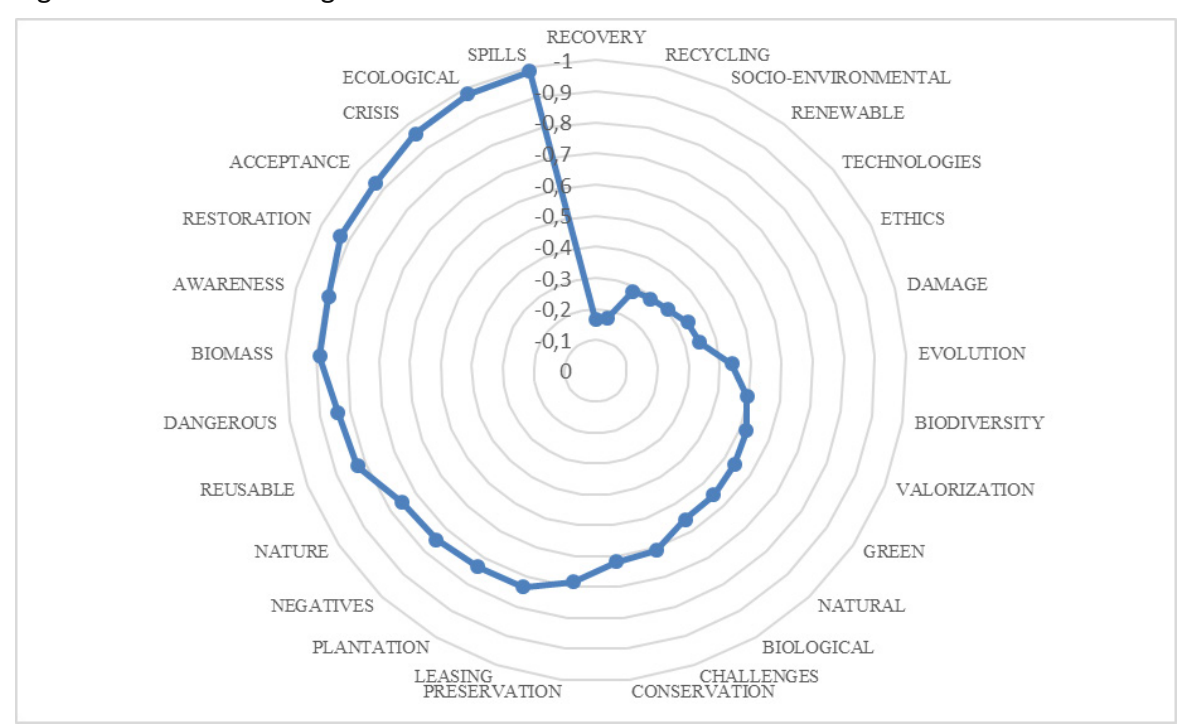

Source: Authors (2019).

Rev. AdM. UfSM, SANTA MARIA, v. 12, Edição Especial XX ENGEMA, P. 1211-1226, 2019 
In general, the analysis of word scores is in agreement with what one might expect. The analysis, however, does not consider the context in which the words occurred in the texts and, therefore, it is not possible to ascertain the meaning in which they appear. Thus, words with a connotation contrary to the concept of sustainability could appear with a positive score and, conversely, words with a sense aligned with sustainability could emerge with a negative score. This limitation, however, does not invalidate the results given the natural tendency to use words in the direct sense.

We found 17 (seventeen) words with positive load on the principal component that represents sustainability and 29 (twenty-nine) with negative load (Figures 1 and 2). In addition, we note that the positive loads are larger and present larger variability while the negative ones are smaller and more homogeneous. Such a result means that companies are more parsimonious in mentioning or relating negative elements.

Words with more expressive scores, both positive and negative, indicate that the content effectively refers to the effects of business operations on the Environment and Sustainability.

It was found that managers tend to avoid negative aspects in voluntary environmental disclosure, as well as to publish information as appropriate and in the absence of a mandatory nature. (ROVER et al, 2008; DE OLIVERIA, MACHADO; BEUREN, 2012). These words provide a clear indication that the companies surveyed seek to communicate to stakeholders a posture of awareness and responsibility. Words like Development, Sustainability, Social, Environment and Risks stand out among those that present positive results. Among those that prevail with negative weights are Spills, Ecological, Crisis, Utilization, Restoration and Awareness.

\section{CONCLUSIONS}

The objective of this article was to analyze the environmental disclosure content of the industrial companies participating in the Corporate Sustainability Index from 2009 to 2016, based on stakeholders' theory. The sample covers five companies from the industrial sector that released the Annual Sustainability Reports in all the years of the analyzed period. Of particular note is the exclusion of financial companies and electric power companies, the latter being subject to specific legislation and regulation.

On basis of content analysis, we selected the words referring to environmental sustainability from the reports. The results indicate that the information evidenced in the Annual Sustainability Reports have highly similar characteristics, since, the estimated correlation coefficients present a level of significance lower than $0.1 \%$. Principal Component Analysis ratified this since it also showed a considerable homogeneity among the companies with regard to the contents disclosed.

The statistical evidence suggests that although companies disclose environmental information, they seek to be in tune with the stakeholder's perspective, as Levitt (1958), Carroll (1979) and Freeman (1984) argue, since the reports are taking into account the specificities of the information users (customers, suppliers, etc.) of each segment. We gathered indications that the diversity of segments in which the surveyed companies operate could have produced greater differentiation between reports if companies were not subject to similar pressures by stakeholders.

The companies are remarkably homogeneous with respect to the dimension called Environmental Impact, which is another indication that, in seeking to meet the different interests, they feel equally pressured to avoid or minimize environmental impacts.

The Principal Component Analysis showed that in choosing words to mention or relate issues related to environmental sustainability, companies are more parsimonious in using words with 
negative connotation, they use a larger set of words with similar frequencies. In opposite, corporations choose a smaller set of words with positive connotation, with higher and varying frequencies.

The research carried out, in the sense of the proposed objective, sought to contribute with new evidence on the characteristics of voluntary disclosure of Brazilian companies, more specifically the information coming from the Annual Sustainability Reports. The results and analysis presented here inform to some extent the manner industrial companies structure environmental disclosure in order to respond to stakeholders' demands. However, although the sampled companies operate in different industrial segments, the use of these results must take into account the period and the size of the sample.

Research work focusing on Annual Sustainability Reports helps to value these reports and to highlight their scope and limitations, and thus provide an incentive for companies to refine their methodologies. Future research could compare the reports of companies segregated according to low, medium and high impact segments according to the National Environmental Policy, considering the evidenced contents.

\section{REFERENCES}

ACERETE, Basilio.; GASCA, Mar.; LLENA, Fernando. Analysis of environmental financial reporting in the Spanish toll roads sector. Spanish Journal of Finance and Accounting/Revista Española de Financiación y Contabilidad, p. 1-34, 2019.

ARGANDOÑA, Antonio. The Stakeholders' Theory and the common good. Journal of Business Ethics, v. 17, n. 9-10, p. 1093-1102, 1998.

B3. Índice de Sustentabilidade Ambiental (ISE), 2018. Disponível em: < http://www.b3.com.br/ pt_br/noticias/ise-2018.htm > acesso em 19.04.2018.

BANERJEE, Subhabrata Bobby. Corporate social responsibility: The good, the bad and the ugly. Critical sociology, v. 34, n. 1, p. 51-79, 2008.

BARDIN, L. Análise de Conteúdo. Trad. Luís Antero Reto e Augusto Pinheiro. Lisboa: Edições 70, 1977.

BRITO, B. M. B. A reação do mercado acionário a eventos ambientais. Dissertação (Mestrado em Administração) - Instituto COPPEAD de Administração, Universidade Federal do Rio de Janeiro, Rio de Janeiro, 2005.

CALIXTO, Laura. Uma análise da evidenciação ambiental de companhias brasileiras - de 1997 a 2005. Journal of Accounting, Management and Governance, v. 10, n. 1, p.9-37, 2007.

CAMPBELL, J. L. Why would corporations behave in socially responsible ways? An institutional theory of corporate social responsibility. Academy of Management Review, v. 32, n. 3, p. 946-967, 2007.

CARROLL, A. B. A three-dimensional conceptual model of corporate performance. Academy of Management Review. v. 4, p. 497-505, 1979.

CINTRA, Y. C. MARTINS, E. De stakeholder a shareholder: a transição dos 'novos Capitalistas'. $1^{\text {st }}$ South American Congress on Social and Environmental Accounting Research - CSEAR 2009. Universidade Federal do Rio de Janeiro 2009. Rio de Janeiro, RJ, Brasil. Anais eletrônicos ... CSEAR, I, 2009. Disponível: http://www.facc.ufrj.br/csear2009/12.pdf. Acesso: 16 de abr. de 2017. 
DE OLIVEIRA, Araceli Farias; MACHADO, Débora Gomes; BEUREN, Ilse Maria. Disclosure Ambiental de Empresas de Setores Potencialmente Poluidores Listadas no Índice de Sustentabilidade Empresarial (ISE). Revista de Gestão Social e Ambiental, v. 6, n. 1, p. 20-37, 2012.

DONALDSON, T.; PRESTON, L. E. The Stakeholders' Theory of the corporation: Concepts, evidence, and implications. Academy of Management Review. v. 20, p. 65-91, 1995.

DUMAY, John; HOSSAIN, MD Amir. Sustainability risk disclosure practices of listed companies in Australia. Australian Accounting Review, v. 29, n. 2, p. 343-359, 2019.

ELKINGTON, J. With Forks: The Triple Bottom Line of 21st Century Business. 1997.

EPSTEIN, M. J. The Identification, Measurement, and Reporting of Corporate Social Impacts: Past, Present, and Future. Advances in Environmental Accounting \& Management, v. 2, p.1-29, 2003.

FGV-EAESP, Fundação Getúlio Vargas e Centro de Estudos em Sustentabilidade. Índice de Sustentabilidade Ambiental (ISE), 2015. Disponível em: < http://isebvmf.com.br/wiki-linha-dotempo-ise/?locale=pt-br> acesso em 19.04.2017

FREEMAN, R. E. Strategic management: A stakeholder approach. Boston, MA: Pitman, 1984.

FREEMAN, R. E.; McVEA, J. A stakeholder approach to strategic management. In: HITT, M.; FREEMAN, E.; HARRISON, J. Handbook of strategic management. Oxford: Blackwell Publishing, 2000. p. 189-207.

FRIEDMAN, Milton. The social responsibility of business is to increase its profits. The New York Times Magazine. New York: September 13, 1970.

FRIEDMAN, Milton; FRIEDMAN, Rose D. Capitalismo e liberdade. Editora Artenova, 1977.

FURTADO, Lorena Lucena et al. Relação entre Sustentabilidade e Inovação: uma análise da legitimidade organizacional das empresas do setor elétrico brasileiro. Revista Catarinense da Ciência Contábil, v. 18, p. 1-16, 2019.

GARRIGA, E. MELÉ, D. Corporate social responsibility theories: mapping the territory. Journal of Business Ethics, v. 53, n.1-2, pp. 51-71, august, 2004.

GIBSON, Robert B. Beyond the pillars: sustainability assessment as a framework for effective integration of social, economic and ecological considerations in significant decisionmaking. Journal of Environmental Assessment Policy and Management, v. 8, n. 03, p. 259-280, 2006.

GIL, Antonio Carlos. Como elaborar projetos de pesquisa. São Paulo, v. 5, n. 61, p. 16-17, 2002.

GRAY, R.; BEBBINGTON, J.; WALTERS, D. Accounting and the Environment. London: Paul Chapman, 1993.

GRAY, R., OWEN, D. ADAMS, C. Accounting and Accountability: changes and challenges in corporate social and environmental reporting, Harlow: Prentice Hall Europe, 1996.

GRAY K. R. Foreign direct investment and environmental impacts-Is the debate over? Review of European Community and International Environmental Law, v. 11, n.3, p. 306-313, 2002. 
GRI, Global Reporting Initiative. Mapping G4 To The GRI Standards - DISCLOSURES - FULL OVERVIEW, (2017). Disponível em: <https://www.globalreporting.org/standards/media/1098/ mapping-g4-to-the-gri-standards-disclosures-full-overview.pdf> acesso em 01.08.2019

GRIFFIN, J. J. MAHON, J. F. The Corporate Social Performance and Corporate Financial Performance Debate. Business and Society, v. 36, n. 1, p. 5-31, 1997.

GRINDE, John; KHARE, Anshuman. The Ant, The Grasshopper Or Schrödinger'S Cat: An Exploration Of Concepts Of Sustainability. Journal of Environmental Assessment Policy and Management, $v$. 10, n. 02, p. 115-141, 2008.

JENSEN, Michael. Value maximization, Stakeholders' Theory, and the corporate objective funcion. Journal of Applied Corporate Finance. New York, v. 14, n. 3, p. 8-21, 2001.

LEVITT, T. The dangers of social responsibility. Harvard Business Review. p. 41-50, 1958.

LÓPEZ, M. V.; GARCIA, A.; RODRIGUEZ, L. Sustainable development and corporate performance: a study based on the Dow Jones Sustainability Index. Journal of Business Ethics, v. 75, p. 285-300, 2007.

MOLDAN, Bedřich; JANOUŠKOVÁ, Svatava; HÁK, Tomáš. How to understand and measure environmental sustainability: Indicators and targets. Ecological Indicators, v. 17, p. 4-13, 2012.

PURVIS, Ben; MAO, Yong; ROBINSON, Darren. Three pillars of sustainability: in search of conceptual origins. Sustainability Science, v. 14, n. 3, p. 681-695, 2019.

ROVER, Suliani et al. Divulgação de informações ambientais nas demonstrações contábeis: um estudo estudo exploratório sobre o disclosure das empresas brasileiras pertecentes a setores de alto impacto ambiental. Revista de Contabilidade e Organizações, v. 3, n. 2, p. 53-72, 2008.

REED, D. J. Stalking the Elusive Business Case for Corporate Sustainability. Washington: World Resources Institute, 2001.

SILVEIRA, A. M.; YOSHINAGA, C. M.; BORBA, P. R. F. Crítica à teoria dos stakeholders como funçãoobjetivo corporativa. Cadernos de Pesquisa em Administração, v. 12, n. 1, p. 33-42, 2005.

STEGER, U. The Business of Sustainability: building industry cases for corporate sustainability. Basingstoke: PalgraveMacmillan, 2004.

TINOCO, João Eduardo P.; KRAEMER, Maria Elizabeth P. Contabilidade e gestão ambiental. São Paulo: Atlas, 2004.

VEIGA, José Eli Da. O âmago da sustentabilidade. estudos avançados, v. 28, n. 82, p. 7-23, 2014.

WAJNBERG, D. Sustentabilidade nos bancos brasileiros: exame da divulgação do relacionamento entre iniciativas socioambientais e o desempenho financeiro corporativo. Concurso Itaú-Unibanco sustentabilidade, 2008. Universidade Federal do Rio de Janeiro 2008. Disponível: <http://www. cra-rj.org.br/site/espaco_opiniao /arquivos/Artigo\%20Daniel\%20Wajnberg.pdf>. Acesso: 15 de abr. de 2018. 


\begin{tabular}{|c|c|c|c|c|}
\hline Contribution & [Author 1] & [Author 2] & [Author 3] & [Author 4] \\
\hline $\begin{array}{c}\text { 1. Definition of research problem } \\
\text { 2. Development of hypotheses or research questions } \\
\text { (empirical studies) }\end{array}$ & $\sqrt{ }$ & $\mathrm{V}$ & & \\
\hline $\begin{array}{c}\text { 3. Development of theoretical propositions } \\
\text { (theoretical work) }\end{array}$ & $\mathrm{V}$ & $\mathrm{V}$ & & \\
\hline 4. Theoretical foundation / Literature review & $\mathrm{V}$ & $\mathrm{V}$ & & \\
\hline 5. Definition of methodological procedures & $\mathrm{V}$ & & $\mathrm{V}$ & \\
\hline 6. Data collection & & & $\mathrm{V}$ & $\mathrm{V}$ \\
\hline 7. Statistical analysis & $\mathrm{V}$ & & $\mathrm{V}$ & \\
\hline 8. Analysis and interpretation of data & & $\mathrm{V}$ & $\mathrm{V}$ & $\mathrm{V}$ \\
\hline 9. Critical revision of the manuscript & $\mathrm{V}$ & & & \\
\hline 10. Manuscript writing & $\mathrm{V}$ & $\mathrm{V}$ & & \\
\hline 11. Other (please specify) & & & & \\
\hline
\end{tabular}

